\title{
A SURVEY OF THE FACTORS AFFECTING THE PRODUCTIVITY OF CONSTRUCTION PROJECTS IN IRAN
}

\section{Parviz Ghoddousi ${ }^{1}$, Mohammad Reza Hosseini ${ }^{2}$}

\author{
${ }^{1}$ Iran University of Science and Technology, Tehran, Iran \\ ${ }^{2}$ University of South Australia, Adelaide, Australia \\ E-mails: ${ }^{1}$ ghoddousi@iust.ac.ir; ${ }^{2 h o s m y 008 @ m y m a i l . u n i s a . e d u . a u ~(c o r r e s p o n d i n g ~ a u t h o r) ~}$
}

Received 28 September 2009; accepted 02 November 2010

\begin{abstract}
The intense competition between the Iranian construction companies has led them to take all appropriate measures to decrease the costs as much as possible. Hence, due to the pivotal role of human resources in construction projects cost, a major part of Iranian construction companies seek their profitability and survival in maximizing the productivity of their operatives. Because of the widespread belief among contractors about the low productivity of daily workers and operatives with basic salary, they commit a major part of their projects activities to sub-contractors. Deployment of sub-contractors by construction firms has become largely conventional in country's construction projects. The aims of this paper is defined as determining the factors and grounds affecting sub-contractors productivity and evaluate their overall negative side effects on project productivity via a structured questionnaire. A total of 31 factors selected and were divided into 7 broad categories. The perceptions of companies managers were asked about the level of effect brought about by the mentioned factors and groups upon productivity on a time based criterion. The analysis indicated that the most important grounds affecting sub-contractors productivity in descending order include: Materials/Tools, Construction technology and method, Planning, Supervision system, Reworks, Weather, and Jobsite condition. Project managers should focus on the identified major grounds and relevant factors in order to improve productivity as long as they commit construction activities to sub-contractors.
\end{abstract}

Keywords: productivity, construction, factors, grounds affecting productivity, sub-contractors, nonproductive time.

Reference to this paper should be made as follows: Ghoddousi, P.; Hosseini, M. R. 2012. A survey of the factors affecting the productivity of construction projects in Iran, Technological and Economic Development of Economy 18(1): 99-116.

JEL Classification: J24, L21, L23. 


\section{Introduction}

Construction projects are assumed to be one of the dominant elements of the economy of all the countries the world over (Proverbs et al. 1999). Logically this sector plays a much more prominent role in developing countries compared with developed countries (Altaf 1979). In addition, this industry is complex in its nature because it comprises large numbers of parties as owners, contractors, consultants, stakeholders, and regulators. Despite this complexity, the industry plays a major role in the development and achievement of society's goals. It is one of the largest industries and contributes to about $10 \%$ of the gross national product (GNP) in industrialized countries (Navon 2005).

Furthermore, recent financial policies introduced by the government have more than doubled the weight of this sector in Iran's economy. Formal governmental authorities say that construction sector's share of total country's budget has been increased from $17.5 \%$ in 2003 to more than $24 \%$ in 2006 and $28.8 \%$ in 2008.

Despite such considerable amount of fund allocated to construction sector, researches in Iran indicated an overall of $51 \%$ of hours loss per operative per site per week, and the activity sampling showed 24-46\% unproductive time variation on these sites (Zakeri et al. 1996)

Above all, the growing large number of registered contractor companies in the country has obliged them to put in a great deal of effort in decreasing the construction costs in order to win the sever competition for contracts.

Taking into account the low productivity of daily and employed operatives, Iranian project managers commit a great deal of their construction activities to sub-contractors in order to decrease the project costs.

In this method the sub-contractors are paid based on the volume of work they perform so, there is no doubt that they put in a constant tireless effort to produce as much as possible. Therefore, they become well-motivated and absolutely determined to do their jobs in the construction site efficiently.

Nowadays, this strategy has become increasingly common amongst most of the Iranian construction companies. In this method, all the required materials, main tools, electricity and other vital prerequisites for doing the construction activities are provided by the main company. The sub-contractors are solely responsible for supplying human resources and will be paid related to the volume of work they complete. Hence, they carry out their works tirelessly.

\section{Aims of this study}

The fundamental aims of the research reported in this paper may be summarized as follows:

- Identification and ranking of factors and grounds affecting the productivity of Iranian sub-contractors.

- Introducing a reasonable approximation of the unproductive time due to the identified grounds in order to show the concrete evidence of their declining effects.

By identifying and prioritizing these grounds and factors, there is a likelihood that manager's awareness could if proper measures are taken, ultimately initiate a positive impact on the productivity of construction projects. 


\section{Productivity background}

Some definitions of productivity may relate to cost. For example, equations (1) and (2) relate productivity to dollars of output per labor cost (Thomas et al. 1990):

$$
\begin{aligned}
& \text { productivity }=\frac{\text { Dollars of output }}{\text { Labor cost }}, \\
& \text { productivity }=\frac{\text { Dollars of output }}{\text { Man-Hour }} .
\end{aligned}
$$

Labor time includes the allocation of time extended on a particular activity by all workers who are involved in producing the completed units. Therefore, reduction of time in one segment of operation could improve the overall production of work.

For the purpose of this study, productivity of each work item is defined as the units of production divided by the corresponding time of workers. Productivity as defined in equation (3) could be considered as a measure of efficiency of workers that converts all various inputs into produced or completed units of work.

$$
\text { productivity }=\frac{\text { completed or produced units }}{\text { corresponding time of workers }} \text {. }
$$

Logically, corresponding time of workers to complete a unit of work can be divided into two separate sections. The minimum rational time spent on direct work or essential contributory work to complete the unit, which is the productive time, and the time wasted on ineffective work or delays (Johnston 2002; Thomas, Daily 1983; Haas et al. 1999).

The minimum duration necessary to complete a unit of a specific work can be considered a relatively fixed time. As a result, the total corresponding time practically spent on a unit of work, fluctuates according to the rate of nonproductive time. In practice, some negative factors increase the nonproductive time.

Eventually, the productivity definition can be revised as formula (4).

$$
\text { productivity }=\frac{\text { Dollars of output }}{\text { Cost of }(\text { productive time }+ \text { nonproductive time })} \text {. }
$$

Actually, the negative factors affecting productivity increase the nonproductive time based on their weight. Hence, the rate of nonproductive time increased by a factor can be considered as a reliable measure to approximate the importance of that factor in declining productivity. This criterion is utilized in this research for measuring the relative power of factors in declining the productivity.

\section{Productivity factors}

The factors influencing construction productivity have been the subject of inquiry by many researchers. In order to improve productivity, a study of the factors affecting it, whether positively or negatively, is necessary. Making use of those factors that positively affect productivity and eliminating or controlling factors that have a negative effect, will ultimately improve productivity. If all factors influencing productivity are known, it will also be possible to forecast productivity (Lema 1995). 
Olomolaiye et al. (1998) indicated that influencing factors are rarely constant and may vary from country to country, from project to project, and even on the same project depending on the circumstances, anything influencing them can subsequently affect productivity.

On the other hand, due to the comparison implicated in their paper by Mojahed and Aghazadeh (2008), they stated that, although major productivity factors may vary amongst projects, companies, and geographical areas, some similarities in issues obstructing productivity could be observed, therefore, lessons learned to overcome productivity challenges at one project may be useful to be applied at another project for productivity improvement.

Goodrum and Haas (2002) suggested that equipment technology is a key factor in longterm improvement in productivity.

Rojas and Aramvareekul (2003) conducted a web-based survey of general contractors, electrical contractors, mechanical contractors, and consultants in USA to examine the factors affecting construction productivity and their opinions on how to improve construction productivity. Management system and strategies, which refers to management skills, scheduling, material and equipment management, and quality control was ranked as having the greatest impact on construction productivity, followed by manpower, industry environment, and external conditions.

Thomas et al. (2002) showed that the variability in project performance is correlated to equipment flow, information, nature of project, construction method, job site congestion, bad weather, out-of sequence work, and workforce management practices.

The various problems that are common at construction projects include disputed change orders, accidents, and theft of material/tools, redo work, lack of material or instructions waiting time, lost or misplaced tools, lack of planning, and attitudes of workforce at project (Adrian 2002).

Other factors identified with influencing labor productivity include poor housekeeping, excessive moving of crafts people from project to project, poor lighting in the work area, lack of adequate ventilation, lack of proper tools or equipment, uncontrolled breaks, shortage of rest rooms and drinking water, high employee turnover, and untimely decisions by supervisors (Johnston 2002; Zakeri et al. 1996).

The survey of construction contracting firms in the water and wastewater treatment plant market in south USA showed that the five most influential productivity drivers at water and wastewater treatment plant construction projects are skills and experience of workforce, management, job planning, motivation, and material availability (Mojahed, Aghazadeh 2008).

Dai et al. (2009) conducted a research in USA to examine the underlying structure of the factors affecting construction productivity from the craft workers' perspective. The results were presented by the following latent factors: construction equipment, materials, tools and consumables, engineering drawing management, direction and coordination, project management, training, Craft worker qualification, superintendent competency, and foreman competency, in a descending order of their negative impact on construction productivity.

Also several researches have carried out some works in issues related to construction labor productivity in developing countries.

By using an activity sampling technique on seven construction sites in Nigeria, problems influencing craftsmen's productivity in order of rank were identified as lack of materials, lack of tools, duplicated efforts or repeated work, instruction delays, inspection delays, absenteeism, incompetency of supervisor, and changing crew members (Olomolaiye et al. 1987). 
Faridi and El-Sayegh (2006) reported that shortage of skills of manpower, poor supervision, poor site management, unsuitable leadership, shortage and breakdown of equipment among others contribute to productivity declining in the United Arab Emirates.

A survey was conducted in Singapore related to productivity issues encountered by contractors at constructions sites by Lim and Alum (1995). Respondents were asked to rank a list of 17 problems that could affect construction productivity. The authors then classified the 17 items into the following three main effective categories: manpower, management, and environment.

Kaming et al. (1997) in their paper revealed that craftsmen in Indonesia spend on average $75 \%$ of their time working productively. The five specific productivity problems were identified as follows: lack of materials, rework, absenteeism, lack of equipment and tools, and gang interference.

Alwi (2003) research, undertaken amongst Indonesian companies, provided strong evidence that small companies are having serious problems related to material management and in completion projects on time. The findings also indicated that smaller companies with limitations of resources such as working capital, technology, equipment, and labor skills believed that they experienced greater waste of productive time compared to larger companies.

In survey studies of project managers in Thailand, the factors identified as causes of nonproductive time were lack of material, incomplete drawings, inspection delay, incompetent supervisors, instruction time, lack of tools and equipment, poor communication, poor site conditions, reworks, absenteeism, and improper site layout (Makulsawaudom, Emsley 2001, 2004).

Survey studies were conducted in Uganda. The researchers found that most workers are not satisfied with the financial situations. They also remarked that workers were not content with the level of training and the state of participation in decision making process which could adversely affect projects productivity (Alinaitwe 2008; Alinaitwe et al. 2009).

According to Mojahed and Aghazadeh (2008), the availability of material problem appears to be the only common major productivity factor among the results obtained by researches done in Iran, Nigeria, Thailand and USA (late 1970s).

Zavadskas et al. (2008) argued that even the contractors' assessment and selection stages should be subjected to taking into consideration the factors that influence the process of construction efficiency.

Enshassi et al. (2007) conducted a survey of building projects in the Gaza Strip. The results indicated that the main 10 factors negatively affecting productivity are material shortages, lack of labor experiences, lack of labor surveillance, misunderstanding between labor and superintendents, drawings and specification alternation during execution, payment delay, labor disloyalty, inspection delay, working seven days per week without holiday, and tool/ equipment shortages. Furthermore, 45 factors considered in the study were divided into 10 groups, which were ranked as follows: materials/tools factors group, supervision factors group, leadership factors group, quality factors group, time factors group, manpower factors group, project factors group, external factors group, motivation factors group, and safety factors group.

Later a questionnaire-based survey was conducted by Enshassi et al. (2009) to elicit the attitude of owners, consultants, and contractors towards factors affecting the performance of construction projects in the Gaza Strip. The results indicated that the average delay because 
of closures leading to materials shortage was the most important performance factor, as it has the first rank among all factors from the perspectives of owners, consultants, and contractors. This agreement between all target groups is traced to the difficult political situation from which the Gaza Strip suffers. The most important factors agreed by the owners, consultants, and contractors as the main factors affecting the performance of construction projects in the Gaza Strip were: escalation of material prices, availability of resources as planned through project duration, average delay because of closures leading to materials shortage, availability of personnel with a high experience and qualifications, quality of equipment and raw materials in project, and leadership skills for project managers.

The Malmquist index method with a novel decomposition technique was employed to estimate the total factor productivity of the Australian construction industry during the period 1990-2007 and to analyze the factors affecting the technological change in the industry by Li and Liu (2010). Results showed that how construction technology, pure technical efficiency and scale economy affect the productivity of construction industry in Australia.

In a research carried out by Rivas et al. (2011), they concentrated on identifying and understanding the productivity factors affecting projects in a Chilean construction company on the basis of questionnaires administered to both direct workers and midlevel employees. The main findings showed that the main arenas affecting construction productivity were somehow related to materials, tools, rework, equipment, truck availability, and the workers' motivational dynamics. Salary expectations were also found to be the most important reason for turnover. In a survey of construction operatives in Iran, results indicated that the five highest-ranking common problems are as follows: materials shortage, weather and site conditions, equipment breakdown, drawing deficiencies/change orders, and lack of proper tools and equipment. The research also stated an overall of $51 \%$ of hour loss per operative per site per week. Above all, the activity sampling showed $24-46 \%$ unproductive time variation on these sites (Zakeri et al. 1996).

\section{Methodology}

\subsection{Data collection}

A review of literature as described was performed to derive a list of factors negatively affecting productivity. As a result, a total of 31 factors relevant to the current situation in Iran, were identified and derived from the literature. The productivity factors were further introduced to a survey instrument to rank the factors and measure perceptions of project managers of the degree of influence of these factors. Based on previous literature review and as advised by local experts, these factors were divided into 7 groups.

The project managers were required to rate the factors in the way they affect productivity in terms of increasing the nonproductive time of activities completion time using their own experiences on construction sites. The questionnaire required the respondents to determine the approximate time added to activities completion time due to the negative effect of each factor. As mentioned earlier, this time was considered to be a percentage of logical essential time to complete the construction activities. In addition, to simplify the answering process, the time percentages were divided into five categories in accordance with Likert Scale. Anyone 
unable to estimate the imposed nonproductive time accurately could rank the negative effect of factors on a Likert Scale as follows:

1. Imposed nonproductive time accounts for less than $20 \%$ of the logical essential time (very low effective).

2. Imposed nonproductive time accounts for $20-40 \%$ of the logical essential time (low effective).

3. Imposed nonproductive time accounts for $40-60 \%$ of the logical essential time (moderately effective).

4. Imposed nonproductive time accounts for $60-80 \%$ of the logical essential time (high effective).

5. Imposed nonproductive time accounts for more than $80 \%$ of the logical essential time (very high effective).

\subsection{Respondents}

Survey through questionnaires was selected as the research method. The studied target population included contractors which have received a valid registration from the related legal authorities. The formal classification among contractors which is now common in Iran, divides the construction companies into 5 categories. The main criteria for classification are related to the company's previous experience, capital, values of the executed projects, staffing, and the financial situation. Those in class 1 are the biggest and undertake projects of the biggest magnitude.

A total of 112 companies were survived. Ninety three companies returned the questionnaires, of which eighty two were duly completed and therefore formed the basis of the analysis reported in this paper.

These results have been achieved by continuous following-up and close personal contact with the managers of contractor companies. The respondents were recognized experts from their respective organizations, mostly directors and general managers with at least 10 years of experience in the construction field. The sample was selected randomly from each level of the 5 contractor's categories. The contractor's union list was ordered by the company number, and 5 lists of contractors were prepared to present the first to the fifth categories. The random selection among the five lists was done by using non-replacement random selection.

\subsection{Data analysis}

When using Likert-type scales it is imperative to calculate and report the internal consistency reliability for any scales or subscales one may be using. So the Cronbach's Alpha reliability test was selected due to the accuracy and simplicity. The reliability analysis resulted that the Cronbach's Alpha coefficient equals 0.8719, which means the data were reliable according to Nunnaly and Bernstein (1994) theory.

The Lilliefors test is a modification of the Kolmogorov-Smirnov test that tests for normality. The test was performed, and the results indicated that the gathered data distribution is none-parametric. 


\subsection{Ranking method}

The statistical parameters like mean, population variance and coefficient of variation, were utilized to rank the factors. The coefficient of variation $(\mathrm{CV})$ was calculated for each variable. This is the variation in standard deviation as a percentage of mean, and is a useful measure for dealing with properties whose standard deviation rises in proportion to the mean.

Since, the scores in each variable are from individuals, it is logical to take these coefficients as a measure of variation in personal/individual assessment of importance (Olomolayie 1988).

We extracted 3 parameters for each of 31 factors based on the answers from respondents including mean, standard deviation, and coefficient of variation.

The mean values of 31 factors were sorted in descending order firstly, and then the factors which their mean values were located in a distance equal to the standard deviation and two times of the standard deviation were divided into separate categories. Then the factors in each mentioned category were ranked in descending order based on their coefficient of variation. The factor in each category with a smaller coefficient of variation was evaluated as the more effective factor. Since the mentioned categories themselves were ranked in descending order earlier, the results of ranking all 31 factors were achieved after this stage.

Some of the used parameters are showed as below.

$$
\begin{gathered}
\overline{\bar{X}}=\frac{\overline{\mathrm{X}}_{1}+\ldots+\overline{\mathrm{X}}_{31}}{\mathrm{~N}}=39.211 \\
\hat{\sigma}=8.38 \\
\overline{\bar{X}} \pm 2 \hat{\sigma}=39.211 \pm 2 \times 8.38=55.97,22.44 \\
\overline{\bar{X}} \pm 1 \hat{\sigma}=39.211 \pm 8.38=47.59,30.83
\end{gathered}
$$

where: $\hat{\sigma}$ : the Standard Deviation, $\overline{\bar{X}}$ : Mean Value.

\section{Results}

As mentioned earlier, in this study, 31 factors declining subcontractor's productivity have been identified and ranked according to their relative importance. Their relative importance was based on the level of effect they exerted on the construction activity's time completion in terms of increasing the nonproductive time.

To simplify the analysis, these factors have been classified into 7 main groups as material/tools, construction method/technology, management/planning, supervision, reworks, weather, and jobsite conditions. Table 1 and Table 2 illustrate the rankings of the 31 factors and defined groups in descending order. It should be mentioned that we utilized the mean values of all the factors in a group as the criteria measure of the respective group (i.e. we achieved 7 mean values for 7 defined groups). To rank the groups the same method for the 31 factors were deployed for 7 groups. It is noteworthy to state that Table 2 merely is presented to show the grouping of the factors (i.e. the factors of the 7 groups shown in Table 2 are not ranked in this stage). 
Table 1. Ranking for productivity declining factors

Declining factors

Rank

\begin{tabular}{|c|c|}
\hline Utilizing the traditional construction methods instead of modern technology & 1 \\
\hline Site manager is not experienced to handle challenges that arise in the field & 2 \\
\hline Lack of proper tools and equipments on-site & 3 \\
\hline Operatives do not pose skills and experience to perform the task & 4 \\
\hline $\begin{array}{l}\text { Site manager does not have the ability in training workers to } \\
\text { perform their jobs properly }\end{array}$ & 5 \\
\hline There is shortage of material in the market & 6 \\
\hline The company executes that type of project for the first time & 7 \\
\hline Materials have not arrived onsite yet & 8 \\
\hline The thermal environment is not comfortable (i.e. heat, cold, humidity) & 9 \\
\hline The tasks are not properly planned and realistically sequenced & 10 \\
\hline The work needs to be redone due to changes in design, drawings or specifications & 11 \\
\hline Skilled workers are not adequate on jobs & 12 \\
\hline There is no construction planning/project schedule in place & 13 \\
\hline $\begin{array}{l}\text { Workers have to adopt awkward postures or exert considerable physical force to } \\
\text { perform the jobs }\end{array}$ & 14 \\
\hline There are frequent tools/equipment breakdowns due to aging or poor maintenance & 15 \\
\hline $\begin{array}{l}\text { The works need to be redone frequently due to poor quality of documents, } \\
\text { drawings or specifications. }\end{array}$ & 16 \\
\hline The jobsite layout is poor & 17 \\
\hline Stoppage because of inspection delays & 18 \\
\hline Disruption of power services & 19 \\
\hline $\begin{array}{l}\text { Congestion and overcrowding on the site/interference among people } \\
\text { working in the jobsite }\end{array}$ & 20 \\
\hline Disruption of water services & 21 \\
\hline The site is slippery or steep imposing terrible conditions & 22 \\
\hline Management does not support safety planning & 23 \\
\hline The work needs to be redone due to the damage after the work was complete & 24 \\
\hline The works need to be redone because it fails quality control inspection or testing & 25 \\
\hline There were errors in fabrication that needs to be corrected in rework & 26 \\
\hline Work and break frequencies and durations are not properly organized & 27 \\
\hline $\begin{array}{l}\text { There are not adequate water coolers, toilets, convenient store or covered rest area } \\
\text { onsite in the vicinity of active work force }\end{array}$ & 28 \\
\hline Considerable distance from home or camping site to jobsite & 29 \\
\hline The jobsite is too noisy/dusty & 30 \\
\hline Low level of lighting/poor ventilation/poor housekeeping/limited accesses & 31 \\
\hline
\end{tabular}


Table 2. Ranking the defined groups and their factors

Materials have not arrived onsite yet

There is shortage of material in the market

Lack of proper tools and equipments on-site

There are frequent tools/equipment breakdowns due to aging or poor maintenance

Operatives do not pose skills and experience to perform the task.

Utilizing the traditional construction methods instead of modern technology

The company executes that type of project for the first time

The site is slippery or steep imposing terrible conditions

Workers have to adopt awkward postures or exert considerable physical force to

perform the jobs

There is no construction planning/project schedule in place

The tasks are not properly planned and realistically sequenced

Skilled workers are not adequate on jobs

Congestion and overcrowding on the site/interference among people working in the jobsite

The jobsite layout is poor

Management does not support safety planning

Site manager does not have the ability in training workers to perform their jobs properly

Stoppage because of inspection delays

Work and break frequencies and durations are not properly organized

Site manager is not experienced to handle challenges that arise in the field

The work needs to be redone due to the damage after the work was complete

The works need to be redone because it fails quality control inspection or testing

There were errors in fabrication that needs to be corrected in rework

The works need to be redone frequently due to poor quality of documents,

drawings or specifications

The work needs to be redone due to changes in design, drawings or specifications

The thermal environment is not comfortable (i.e. heat, cold, humidity)

There are not adequate water coolers, toilets, convenient store or covered rest area onsite in the vicinity of active work force

Considerable distance from home or camping site to jobsite

The jobsite is too noisy/dusty

Low level of lighting/poor ventilation/poor housekeeping/limited accesses

Disruption of water services

Disruption of power services 


\section{Discussion}

This section contains the results from the ratings as given in Table 1 and Table 2. The groups are discussed on descending order based on their rank in Table 2. Tables 3 to Table 8 also show the relative ranking of the factors inside each group. These rankings inside each of the mentioned tables were achieved based on the rankings of 31 factors in Table 1.

\subsection{Material/tools}

Table 3 illustrates the ranking of the 4 factors in the group related to material/tools. As mentioned earlier, Material/tools issues were defined as the main declining issues in past researches in Iran which appears consistent with the achieved results of this study.

Table 3. Ranking material/tools factors

\begin{tabular}{lc}
\hline \multicolumn{1}{c}{ Factors } & Rank \\
\hline Lack of proper tools and equipments on-site & 1 \\
\hline There is shortage of material in the market & 2 \\
\hline Materials have not arrived onsite yet & 3 \\
\hline $\begin{array}{l}\text { There are frequent tools/equipment breakdowns due to } \\
\text { aging or poor maintenance }\end{array}$ & 4 \\
\hline
\end{tabular}

This group consists of 4 factors in which lack of proper tools and equipment is defined as the main cause of adding nonproductive time to construction activities completion time. This factor is the direct consequence of some situations as follows: poor financial strength of the company, inappropriate site preparation, company's unwillingness to purchase proper tools and equipments.

Truly, the payments made to Iranian contractors are highly irregular. Hence, they cannot possibly afford to buy the required materials in time. In addition, contractors are not sure about the continuity of their work. As a result, they purchase the essential tools just when they need them which leads to a large amount of nonproductive time during construction activities. Furthermore, the tools are not properly made and kept onsite in a safe and secure location which can cause damage or theft.

The prohibitive price of construction equipments can be the major obstacle for companies wishing to purchase them. Therefore, the irregularities due to old equipment disorders appear inevitable. To sum up, Iranian construction projects commonly encounter problems in the materials/tools ground as follows:

- The major part of equipments is fairly old, and purchasing new equipments is next to impossible for many companies due to their prohibitive price.

- Irregular payments lead to poor procurements and remain as serious obstacles in the path of purchasing materials in time.

- Poor procurement planning.

It is obvious that project managers have little control over many of the mentioned difficulties, but these problems could be predicted and considered in project scheduling at first. 


\subsection{Construction method/technology}

Table 4 shows the ranking of the 5 factors in this ground. The traditional and old fashioned technology is still common in country's construction projects. It is clear that this problem ends up in delays, cost overruns, and waste of resources. This factor is determined as the greatest declining factor in country's construction industry as illustrated in Table 1. Since, in many occasions we must utilize several crews and skilled workers to do a specific job using traditional methods. This activity would be completed by one group of operatives much faster, using less resource, if we utilized modern technology.

Table 4. Ranking construction method/technology factors

\begin{tabular}{lc}
\hline \multicolumn{1}{c}{ Factors } & Rank \\
\hline $\begin{array}{l}\text { Utilizing the traditional construction methods instead of } \\
\text { modern technology }\end{array}$ & 1 \\
\hline $\begin{array}{l}\text { Operatives do not pose skills and experience to perform } \\
\text { the task }\end{array}$ & 2 \\
\hline The company executes that type of project for the first time & 3 \\
\hline The site is slippery or steep imposing terrible conditions & 4 \\
\hline $\begin{array}{l}\text { Workers have to adopt awkward postures or exert } \\
\text { considerable physical force to perform the jobs }\end{array}$ & 5 \\
\hline
\end{tabular}

Furthermore, a major part of construction operatives have gained skills merely from longterm experiences. Hence, they strongly resist any sort of change. Since, it takes them a long time to become competent in a new method of working. As a result, this factor is ranked as the second important element declining productivity in this group.

Construction operatives have become extremely tolerant of jobsite problems. Therefore, actually the relevant factors are not important anymore.

\subsection{Management/planning}

Management/planning issues in this paper are considered as high-level management and long-term planning which is provided by senior managers of the company. Table 5 illustrates the ranking of 6 factors under this issue.

Table 5. Ranking management/planning factors

\begin{tabular}{lc}
\hline \multicolumn{1}{c}{ Factors } & Rank \\
\hline $\begin{array}{l}\text { The tasks are not properly planned and realistically } \\
\text { sequenced }\end{array}$ & 1 \\
\hline Skilled workers are not adequate on jobs & 2 \\
\hline There is no construction planning/project schedule in place & 3 \\
\hline The jobsite layout is poor & 4 \\
\hline $\begin{array}{l}\text { Congestion and overcrowding on the site/interference } \\
\text { among people working in the jobsite }\end{array}$ & 5 \\
\hline Management does not support safety planning & 6 \\
\hline
\end{tabular}


As showed in Table 1 there is not much difference amongst the importance of these factors in declining productivity. Therefore, all of them can be easily defined in terms of: negligence on the prominent role of planning/project schedule. Actually, even in many large-scale projects the planning schedule is seen as a formality and is not expected to have a great effect on decision-making process, let alone small projects. This fact brings about an adverse direct effect on the procurement process as mentioned earlier.

It is obvious that site layout and safety regulations are not matters of great importance among Iranian project managers.

Congestion and overcrowding rarely happens in jobsites, since the lack of skilled workers and operatives has a much greater adverse effect on productivity, as results indicate.

To sum up, the main declining factors regarding management/planning issues are determined as follows:

- Common negligence on the prominent role of planning/project schedule.

- Not taking into account the planned schedule in the decision makings process.

- Common negligence on the key role of site layout, and safety related issues.

\subsection{Supervision}

In this paper, supervision term refers to the direct management performed by the site manager, and the supervision offered by the consulting engineers. Table 6 shows the ranking of the factors under this ground.

Table 6. Ranking supervision factors

\begin{tabular}{lc}
\hline \multicolumn{1}{c}{ Factors } & Rank \\
\hline $\begin{array}{l}\text { Site manager is not experienced to handle challenges that } \\
\text { arise in the field }\end{array}$ & 1 \\
\hline $\begin{array}{l}\text { Site manager does not have the ability in training workers to } \\
\text { perform their jobs properly }\end{array}$ & 2 \\
\hline Stoppage because of inspection delays & 3 \\
\hline $\begin{array}{l}\text { Work and break frequencies and durations are not properly } \\
\text { organized }\end{array}$ & 4 \\
\hline
\end{tabular}

Table 1 indicates that the second important declining factor in project manager's perception is the weakness of site manager in handling the jobsite challenges. In addition, according to the fifth ranked factor, site manager should have the ability in training workers to perform their jobs properly. These findings seem consistent with Iranian contractor's widespread belief about the crucial role of site manager in a construction project. Idle times due to inspection delay and uncontrolled breaks are not recognized to be very effective in declining productivity.

\subsection{Reworks}

Table 7 illustrates the ranking of the reworks factors. The most important factor under this group is ranked the eleventh in Table 1 . The next one is ranked as the sixteenth declining 
factor. These two factors are very common in Iran, and they are the direct cause of many delays and cost overruns.

The remained factors are not determined to be of great importance. This phenomenon arises out of this fact that in Iranian construction projects, high speed of completion far outweighs the quality of work. Therefore, these factors do not show a high level of ability in declining productivity.

Table 7. Ranking reworks factors

\begin{tabular}{lc}
\hline \multicolumn{1}{c}{ Factors } & Rank \\
\hline $\begin{array}{l}\text { The work needs to be redone due to changes in design, } \\
\text { drawings or specifications }\end{array}$ & 1 \\
\hline $\begin{array}{l}\text { The works need to be redone frequently due to poor quality } \\
\text { of documents, drawings or specifications }\end{array}$ & 2 \\
\hline $\begin{array}{l}\text { The work needs to be redone due to the damage after the } \\
\text { work was complete }\end{array}$ & 3 \\
\hline $\begin{array}{l}\text { The work needs to be redone because it fails quality control } \\
\text { inspection or testing }\end{array}$ & 4 \\
\hline $\begin{array}{l}\text { There were errors in fabrication that needs to be corrected } \\
\text { in rework }\end{array}$ & 5 \\
\hline
\end{tabular}

\subsection{Weather}

This research considers the adverse weather and thermal conditions as one particular factor. This factor is ranked as the sixth most important ground among the 7 groups and the ninth declining factor amongst the factors negatively affecting productivity. Generally, construction projects take place in an open environment, thus environmental conditions may impact the condition of jobsite as well as workers.

\subsection{Jobsite condition}

The ranking of the 6 factors in the group related to jobsite conditions is shown in Table 8 . As Table 1 indicates, a major part of factors under this ground appears to have the least importance among 31 factors.

Table 8. Ranking jobsite condition factors

\begin{tabular}{lc}
\hline \multicolumn{1}{c}{ Factors } & Rank \\
\hline Disruption of power services & 1 \\
\hline Disruption of water services & 2 \\
\hline $\begin{array}{l}\text { There are not adequate water coolers, toilets, convenient store } \\
\text { or covered rest areas onsite in the vicinity of active work force }\end{array}$ & 3 \\
\hline Considerable distance from home or camping site to jobsite & 4 \\
\hline The jobsite is too noisy/dusty & 5 \\
\hline $\begin{array}{l}\text { Low level of lighting/poor ventilation/poor housekeeping/ } \\
\text { limited accesses }\end{array}$ & 6 \\
\hline
\end{tabular}


This group is the seventh effective ground among 7 mentioned grounds. This level of negligence arises from the recent improvements in jobsite conditions in Iran.

Above all, working crews do not pay much attention to these issues. Actually, Iranian operatives do not assign a high priority to the job conveniences, and companies are not obliged to provide.

\section{Approximation of the grounds declining effects}

This object of our research was aimed at presenting an approximation of the effect level of the grounds studied in this paper. The effect level is measured based on the amount of nonproductive time added to the completion time of activities due to the factors or grounds. This measure is defined as a percentage of logical essential time required to complete activities. Table 9 illustrates an approximation of this time due to the negative effect of the mentioned grounds. The data in this table are based on the basic notion of 95\% Confidence Interval for Mean achieved from SPSS output.

Table 9. Approximation of added time due to the grounds

\begin{tabular}{lcc}
\hline \multicolumn{1}{c}{ Groups } & $\begin{array}{c}\text { Maximum } \\
\text { Time Added }\end{array}$ & $\begin{array}{c}\text { Minimum Time } \\
\text { Added }\end{array}$ \\
\hline Material/tools & 50 & 43 \\
\hline Construction method/technology & 46 & 41 \\
\hline Management/planning & 41 & 36 \\
\hline Supervision & 46.5 & 39 \\
\hline Rework & 33 & 39 \\
\hline Weather & 48 & 38 \\
\hline Jobsite Condition & 32 & 26 \\
\hline
\end{tabular}

\section{Conclusions}

In this study, 31 factors influencing sub-contractors productivity in Iran were examined by bringing them together in 7 main groups. The results indicated that the main 10 factors negatively affecting labor productivity in descending order are as follows:

1. Utilizing the traditional construction methods instead of modern technology.

2. Site manager is not experienced to handle challenges that arise in the field.

3. Lack of proper tools and equipments on-site.

4. Operatives do not posses skills and experience to perform the task.

5. Site manager does not have the ability in training workers to perform their jobs properly.

6. There is shortage of material in the market.

7. The company executes that type of project for the first time.

8. Materials have not arrived onsite yet.

9. The thermal environment is not comfortable (i.e. heat, cold, humidity).

10. The tasks are not properly planned and realistically sequenced. 
Furthermore, 31 factors considered in the study were divided into 7 groups, which were ranked according to their importance as follows:

1. Material/tools.

2. Construction method/technology.

3. Management/planning.

4. Supervision.

5. Reworks.

6. Weather.

7. Jobsite condition.

Therefore, the results indicate that the main problems identified in past researches in Iran still have remained the predominant obstacles in the path of increasing productivity. In addition the lack of materials and tools is identified as the main declining group in this paper.

Our results are also generally consistent with the results of similar researches carried out in Nigeria, Thailand, and Indonesia (Olomolaiye et al. 1987; Kaming et al. 1997; Makulsawaudom, Emsley 2001, 2004), and are absolutely similar to results achieved in the Gaza Strip (Enshassi et al. 2007). The results also have a general likeliness with the points made by Mojahed and Aghazadeh (2008).

Achieved outcomes make it imperative that contracting companies should provide a materials supply schedule for each of their projects. This schedule should include the time required to supply materials and the availability of materials on the local market to furnish the required materials in time. Contracting companies should also select a suitable storage location for purchased materials in each project, which should be easily accessible and close to active work area to avoid wastage of labor time for multiple-handling materials.

Contracting companies have to pay more attention to the quality of construction materials and tools used in their projects, as using appropriate materials and tools reduces both the time taken to finish the work and wastage of materials. Using appropriate materials and tools also has a positive effect on the quality of work, which consequently improves labor productivity. In addition, it prevents from failures arising from quality inspections and testing.

Tremendous efforts should be made by contracting companies and policy makers to benefit from what other developed countries have achieved through technology transfer, and replacing traditional methods with new ones rapidly. This issue could be considered in the process of training engineers and operatives, since it is one of the dominant factors influencing on the productivity of construction projects in Iran.

The construction policy makers should make attempt to increase the use of project scheduling techniques such as Microsoft project and Primavera in this industry. Even they have to lay down strict rules about utilizing project scheduling methods in all construction projects in the country.

As a result, it can be concluded that the majority of the highest effective factors are all financial related, reflecting the financial weakness of the majority of Iranian construction companies due to the payment irregularities by the governmental sector.

The fact that the jobsite conditions have the lowest importance among the groups seems quite normal in terms of noticeable recent improvements of the work atmosphere in Iran. 


\section{References}

Adrian, J. J. 2002. Improving jobsite production, Masonry Construction 15(3): 14-19.

Alinaitwe, H. M. 2008. An Assessment of clients' performance in having an efficient building process in Uganda, Journal of Civil Engineering and Management 14(2): 73-78.

http://dx.doi.org/10.3846/1392-3730.2008.14.1

Alinaitwe, H.; Mwakali, J. A.; Hansson, B. 2009. Organizational effectiveness of Ugandan building firms as viewed by craftsmen, Journal of Civil Engineering and Management 15(3): 281-288. http://dx.doi.org/10.3846/1392-3730.2009.15.281-288

Altaf, H. 1979. Construction productivity factors, Journal of Professional Activities, ASCE 105(E14): 189-195.

Alwi, S. 2003. Factors Influencing Construction Productivity in the Indonesian Context, in Proceedings the 5th EASTS Conference. Fukuoka, Japan.

Dai, J.; Goodrum, P. M.; Maloney, W. F.; Srinivasan, C. 2009. Latent structures of the factors affecting construction labor productivity, Journal of Construction Engineering and Management 135(5):397-406. http://dx.doi.org/10.1061/(ASCE)0733-9364(2009)135:5(397)

Enshassi, A.; Mohamed, S.; Abu Mustafa, Z.; Mayer, P. E. 2007. Factors affecting labor productivity in building projects in the Gaza Strip, Journal of Civil Engineering and Management 13(4): 245-254. http://dx.doi.org/10.1080/13923730.2007.9636444

Enshassi, A.; Mohamed, S.; Abushaban, S. 2009. Factors affecting the performance of construction projects in the Gaza Strip, Journal of Civil Engineering and Management 15(3): 269-280. http://dx.doi.org/10.3846/1392-3730.2009.15.269-280

Faridi, A.; El-Sayegh, S. 2006. Significant factors causing delay in the UAE construction industry, Journal of Construction Management and Economics 24(11): 1167-1176. http://dx.doi.org/10.1080/01446190600827033

Goodrum, P. M.; Haas, C. T. 2002. Partial factor productivity and equipment technology change at activity level in US construction industry, Journal of Construction Engineering and Management 128(6): 463-472. http://dx.doi.org/10.1061/(ASCE)0733-9364(2002)128:6(463)

Haas, C. T.; Borcherding, J. D.; Allmon, E.; Goodrum, P. M. 1999. U.S. Construction Labor Productivity Trends 1970-1998. (Rep. No. 7). Center for Construction Industry Studies, University of Texas at Austin.

Johnston, H. 2002. Productivity and the work flow process, in ASC Proceedings of the 38th Annual Conference. Blacksburg, VA, 157-164.

Kaming, P. F.; Olomolaiye, P. O.; Holt, G. D.; Harris, F. C. 1997. Factors influencing craftsmen's productivity in Indonesia, International Journal of Project Management 15(1): 21-30. http://dx.doi.org/10.1016/S0263-7863(96)00019-1

Lema, N. M. 1995. Construction of Labour Productivity Modeling. University of Dar Elsalaam.

Lim, E. C.; Alum, J. 1995. Construction productivity: issues encountered by contractors in Singapore, Journal of Construction Engineering and Management 126(2): 137-141.

Makulsawaudom, A.; Emsley, M. W. 2001. Factors affecting the productivity of the construction industry in Thailand: the project managers' perception, in ARCOM Seventeenth Annual Conference, vol. 1. September 5-7, 2001. University of Salford, 280-291.

Makulsawaudom, A.; Emsley, M. W. 2004. Critical factors influencing construction productivity in Thailand, The Journal of KMITNB 14(3): 1-6.

Mojahed, S.; Aghazadeh, F. 2008. Major factors influencing productivity of water and wastewater treatment plant construction: evidence from the deep south USA, International Journal of Project Management 26: 195-202. http://dx.doi.org/10.1016/j.ijproman.2007.06.003

Navon, R. 2005. Automated project performance control of construction projects, Automation in Construction 14: 467-476. http://dx.doi.org/10.1016/j.autcon.2004.09.006

Nunnally, J. C.; Bernstein, I. H. 1994. Psychometric Theory. 3rd ed. New York: McGraw-Hill. 
Olomolaiye, P. O.; Wahab, K. A.; Price, A. D. F. 1987. Problems influencing craftsmen's productivity in Nigeria, Building and Environment 22(4): 316-324. http://dx.doi.org/10.1016/0360-1323(87)90024-2

Olomolaiye, P. O. 1988. An Evaluation of Bricklayers' Motivation and Productivity: Ph.D. Thesis. Department of Civil Engineering, Loughborough University of Technology, Loughborough.

Olomolaiye, P. O.; Jayawardane, A. K. W.; Harris, F. C. 1998. Construction Productivity Management. Wesley Longman.

Proverbs, D. G.; Holt, G. D.; Olomolaiye, P. O. 1999. Factors impacting construction project duration: a comparison between France, Germany and the U.K., Building and Environment 34: 197-204. http://dx.doi.org/10.1016/S0360-1323(98)00004-3

Rivas, R. A.; Borcherding, J. D.; Gonzalez, V.; Alarcón, L. F. 2011. Analysis of factors influencing productivity using craftsmen questionnaires: case study in a Chilean construction company, Journal of Construction Engineering and Management 137(4): 312-320. http://dx.doi.org/10.1061/(ASCE)CO.1943-7862.0000274

Rojas, E. M.; Aramvareekul, P. 2003. Labor productivity drivers and opportunities in the construction industry, Journal of Management in Engineering 129(2): 78-82. http://dx.doi.org/10.1061/(ASCE)0742-597X(2003)19:2(78)

Thomas, H. R.; Daily, J. 1983. Crew performance measurement via activity sampling, Journal of Construction Engineering and Management 109(3): 309-334. http://dx.doi.org/10.1061/(ASCE)0733-9364(1983)109:3(309)

Thomas, H. R.; Maloney, W. F.; Horner, M. W. 1990. Modeling construction labor productivity, Journal of Construction Engineering and Management 116(4): 705-726. http://dx.doi.org/10.1061/(ASCE)0733-9364(1990)116:4(705)

Thomas, H. R.; Horman, M. J.; Souza, U. E.; Zaviski, I. 2002. Reducing variability to improve performance as a lean construction principle, Journal of Construction Engineering and Management 128(2): 144-154. http://dx.doi.org/10.1061/(ASCE)0733-9364(2002)128:2(144)

Yan Li; Chunlu Liu. 2010. Malmquist indices of total factor productivity changes in the Australian construction industry, Construction Management and Economics 28(9): 933-945. http://dx.doi.org/10.1080/01446191003762231

Zakeri, M.; Olomolaiye, P.; Holt, G. D.; Harris, F. C. 1996. A survey of constraints on Iranian construction operatives' productivity, Construction Management and Economics 14: 417-426. http://dx.doi.org/10.1080/014461996373287

Zavadskas, E. K.; Turskis, Z.; Tamosaitiene, J. 2008. Contractor selection of construction in a competitive environment, Journal of Business Economics and Management 9(3): 181-187.

http://dx.doi.org/10.3846/1611-1699.2008.9.181-187

Parviz GHODDOUSI is an associate professor of Civil Engineering at Iran University of Science and Technology. He received his BE at Bangalore University, India, in 1980, his MS at University of Leeds in Construction Engineering in 1987, and his PhD at University of Leeds, England, in 1992. He lectures in the field of project management, Project Planning and Control, equipment and methods, concrete technology. He has published eight books in Persian and more than fifty national and international papers on construction engineering and concrete technology. His main research interests consist of project management and concrete durability.

Mohammad Reza HOSSEINI is a Civil Engineer and the C.E.O of a construction company which has carried out projects all over Iran. He has been conducting many researches for the Building code office of Iran's Ministry of Housing for five years, and has been co-author for two books published by that office. He has gained practical experience of the construction industry for more than eleven years. He has received his MS in Construction Management field at Iran University of Science and Technology, and his main research fields are productivity, earned value, benchmarking and project performance. He is a $\mathrm{PhD}$ candidate in Construction Management at the University of South Australia at the present time. 